\title{
Pilchard orthomyxovirus (POMV). I. Characterisation of an emerging virus isolated from pilchards Sardinops sagax and Atlantic salmon Salmo salar
}

\author{
Peter G. Mohr ${ }^{1, *}$, Mark St. J. Crane ${ }^{1}$, John Hoad ${ }^{1}$, Lynette M. Williams ${ }^{1}$, \\ David Cummins ${ }^{1}$, Matthew J. Neave ${ }^{1}$, Brian Shiell ${ }^{1}$, Gary Beddome ${ }^{1}$, \\ Wojtek P. Michalski ${ }^{1}$, Grantley R. Peck ${ }^{1}$, Francisca Samsing ${ }^{2}$, James W. Wynne ${ }^{2}$, \\ Sandra G. Crameri ${ }^{1}$, Alexander D. Hyatt ${ }^{1}$, Nicholas J. G. Moody ${ }^{1}$ \\ ${ }^{1}$ CSIRO Australian Animal Health Laboratory, 5 Portarlington Rd, East Geelong, Victoria 3220, Australia \\ ${ }^{2}$ CSIRO Agriculture and Food, Aquaculture Program, Castray Esplanade, Battery Point, Tasmania 7004, Australia
}

\begin{abstract}
An orthomyxo-like virus was first isolated in 1998 as an incidental discovery from pilchards Sardinops sagax collected from waters off the South Australian coast. In the following 2 decades, orthomyxo-like viruses have been isolated from healthy pilchards in South Australia and Tasmania. In 2006, an orthomyxo-like virus was also isolated from farmed Atlantic salmon Salmo salar in Tasmania during routine surveillance and, again, from 2012 onwards from diseased Atlantic salmon. Using transmission electron microscopy, these viruses were identified as belonging to the family Orthomyxoviridae. To further characterise the viruses, the genomes of 11 viral isolates were sequenced. The open reading frames (ORFs) that encode 10 putative proteins from 8 viral genome segments were assembled from Illumina MiSeq next generation sequencing (NGS) data. The complete genome of a 2014 isolate was also assembled from NGS, RNA-sequencing (RNA-seq) data, that included conserved motifs that shared commonalities with infectious salmon anaemia virus, rainbow trout orthomyxovirus and Influenzavirus A. The presence of 8 viral proteins translated from genome segments was confirmed by mass spectrometric analysis including 2 novel proteins with no known orthologs. Sequence analysis of the ORFs, non-coding regions and proteins indicated that the viruses had minimal diversity and hence were named pilchard orthomyxovirus (POMV), based on the fish host species of its first isolation. The low homology of POMV proteins with previously characterised orthomyxoviruses suggests that POMV is the first virus to be characterised from a new genus within the Orthomyxoviridae. To facilitate more rapid detection and subsequent diagnostic confirmation of POMV infections, TaqMan and conventional nested PCRs were designed.
\end{abstract}

KEY WORDS: Orthomyxovirus · Pilchard · Sardinops sagax · Atlantic salmon · Salmo salar • Australia

\section{INTRODUCTION}

A mass mortality event in wild pilchards Sardinops sagax occurred around the southern coast of Australia (Hyatt et al. 1997, Whittington et al. 1997) in 1995

${ }^{*}$ Corresponding author: peter.mohr@csiro.au and was followed by a similar event in 1998 and 1999. In both incidents, a herpesvirus was observed in gill epithelial lesions, and it was concluded that the fish died from hypoxia due to impaired gill function. During the investigation of both mortality events, 
numerous tissue samples from affected pilchards were processed for virus isolation using cultures of several fish cell lines. The pilchard herpesvirus could not be grown in any of the cell lines used and prompted the development of pilchard cell lines (Williams et al. 2003). During the process to establish pilchard cell lines using tissues from healthy pilchards obtained from locations geographically distant from the on-going pilchard mortalities, the pilchard tissues were also routinely examined for viruses by culture in established cell lines from several other fish species. Viral-like cytopathic effect (CPE) was observed in cultures of the Chinook salmon embryo cell line, CHSE-214 (ATCC CRL 1681), and an orthomyxo-like virus was isolated, which was assumed to be purely incidental and not associated with the pilchard mass mortality events. The virus, tentatively named pilchard orthomyxovirus (POMV), was forwarded to the Norwegian Veterinary Institute, Oslo, where it was confirmed that this orthomyxovirus was not infectious salmon anemia virus (B. Dannevig pers. comm.). Following this first isolation, the virus has been recovered from healthy pilchards when surveillance has been undertaken, including around tuna farms in South Australia. Furthermore, in 2006, another orthomyxo-like virus with morphological properties similar to those of the pilchard virus was isolated during routine health surveillance testing of farmed Atlantic salmon in northern Tasmania, Australia. This virus also tested negative for infectious salmon anaemia virus (ISAV) using the standard diagnostic tests available (OIE 2019a) and was tentatively named salmon orthomyxovirus (SOMV). In 2012, further orthomyxo-like virus isolates were obtained from diseased Atlantic salmon farmed in south-eastern Tasmania. The relationship between orthomyxo-like viruses isolated from pilchards and Atlantic salmon was unknown, and this report is the first to confirm that POMV and SOMV are indeed the same virus and describes the comprehensive characterisation of the viruses leading to the development of molecular diagnostic tests for their detection and identification.

\section{MATERIALS AND METHODS}

\subsection{Virological examination}

For virus isolation from pilchards and Atlantic salmon, submissions of pooled tissues of kidney, liver and spleen were processed using standard procedures (OIE 2019b). Briefly, duplicate 1 to 2 d old cul- tures (at 90\% cell confluency) of CHSE-214 (Chinook salmon embryo cell line; ATCC CRL 1681), RTG-2 (rainbow trout gonad cell line; ATCC CCL 55) and EPC (epithelioma papulosum cyprini cell lines; Fijan et al. 1983, Winton et al. 2010), established in 24-well culture plates, were inoculated with $150 \mu$ l aliquots of 1:10 and 1:100 dilutions of clarified tissue homogenates. Each inoculum was adsorbed for $1 \mathrm{~h}$ at $15^{\circ} \mathrm{C}$, and then the following media were added per well to yield approximate final tissue sample dilutions of 1:100 and 1:1000: $1.5 \mathrm{ml}$ culture medium Minimal Essential Medium with Earle's salts (MEM) for CHSE214 cultures; Leibovitz's L-15 medium for EPC cultures; MEM with $1.5 \mathrm{~g} \mathrm{l}^{-1}$ sodium bicarbonate for RTG-2 cultures, containing $2 \%$ (v/v) foetal bovine serum (FBS), $2 \mathrm{mM}$ glutamine and $100 \mathrm{IU} \mathrm{ml}^{-1}$ penicillin and $100 \mu \mathrm{g} \mathrm{ml}^{-1}$ streptomycin. Cultures were incubated at $15^{\circ} \mathrm{C}$ in either an atmosphere of $5 \%$ carbon dioxide/95\% air (CHSE-214 cultures) or normal atmosphere (RTG-2 and EPC cultures). At 7 to $10 \mathrm{~d}$ post-inoculation (p.i.), material from cultures displaying CPE was passaged directly on to fresh cell cultures that were incubated, as described above. Tissue culture supernatant (TCSN) fluids and cells from the same test sample were pooled from 4 wells, $0.45 \mu \mathrm{m}$-filtered, and samples inoculated onto wells of 1 to $2 \mathrm{~d}$ old cell cultures in 24-well plates. When CPE was evident, TCSNs from these cultures were passed onto cell cultures growing on Thermanox ${ }^{\mathrm{TM}}$ coverslips (NUNC) in 24-well plates. When CPE developed, the coverslip cultures were fixed and processed for electron microscopy for confirmation of orthomyxovirus infection. In this way, several orthomyxovirus isolates were obtained in cell culture during routine surveillance and disease investigation activities in South Australia and Tasmania and were used as part of this study to characterise the viruses (Table 1). Other cell lines FHM (fathead minnow cell line; ATCC CCL 42), SHK-1 (Atlantic salmon head kidney cell line; Dannevig et al. 1995) and PL (pilchard liver cell line; Williams et al. 2003) were also used in attempts to amplify the virus.

\subsection{Electron microscopy}

Cell cultures (CHSE-214) displaying CPE were processed for negative contrast electron microscopy (NCEM). Cell culture supernatant fluid was adsorbed to parlodion-filmed, carbon-coated, 400-mesh copper grids. The adsorbed material was then stained with $2 \%$ (w/v) phosphotungstic acid ( $\mathrm{pH} 6.5)$. For ultrathin sections, coverslip cultures were fixed 
Table 1. Origin of pilchard orthomyxovirus isolates sequenced by next generation sequencing

\begin{tabular}{|lcllll|}
\hline Isolate ID & $\begin{array}{c}\text { Year } \\
\text { isolated }\end{array}$ & Fish species & Health status & Location & $\begin{array}{c}\text { No. of passages } \\
\text { in CHSE-214 }\end{array}$ \\
\hline $98-01382$ & 1998 & Pilchard & Healthy & Spencer Gulf, South Australia & 4 \\
$06-04216$ & 2006 & Atlantic salmon & Healthy & Tamar River, Northern Tasmania & 3 \\
$07-01002$ & 2007 & Pilchard & Healthy & Port Lincoln, South Australia & 4 \\
$12-01390$ & 2012 & Atlantic salmon & Diseased & Huon River, Southern Tasmania & 3 \\
$12-02055$ & 2012 & Atlantic salmon & Diseased & Dover, Southern Tasmania & 3 \\
$12-02935$ & 2012 & Atlantic salmon & Diseased & Bruny Island, Southern Tasmania & 3 \\
$13-01407$ & 2013 & Atlantic salmon & Diseased & Nubeena, Southern Tasmania & 3 \\
$13-02097$ & 2013 & Atlantic salmon & Diseased & Huon River, Southern Tasmania & 3 \\
$13-03566$ & 2013 & Atlantic salmon & Diseased & Tamar River, Northern Tasmania & 3 \\
$13-03672$ & 2013 & Pilchard & Healthy & Nubeena, Southern Tasmania & 3 \\
$14-01514$ & 2014 & Atlantic salmon & Diseased & Huon River, Southern Tasmania & 2 \\
\end{tabular}

in $2.5 \%$ (v/v) glutaraldehyde in $0.1 \mathrm{M}$ cacodylate buffer ( $\mathrm{pH} 7.2)$, washed in the same buffer, post-fixed in $1 \%(\mathrm{w} / \mathrm{v})$ osmium tetroxide, rinsed in water and dehydrated through a graded series of ethanol. Specimens were then infiltrated and embedded in Spurr's epoxy resin. Sections were cut on a Leica-Reichert ultracut IIE microtome and stained in uranyl acetate followed by lead citrate. In addition, control cell samples were obtained from uninfected cell cultures. Grids were examined using a Philips CM120 transmission electron microscope at $120 \mathrm{kV}$.

\subsection{MiSeq next generation sequencing}

Eleven orthomyxo-like virus isolates were selected for next generation sequencing (NGS). The isolates were obtained from samples submitted between 1998 and 2014 from pilchards and Atlantic salmon in South Australia and Tasmania and archived (frozen at $-80^{\circ} \mathrm{C}$ ) as cell culture supernatants (Table 1). CHSE-214 cell cultures were inoculated with each of the thawed isolates, incubated at $15^{\circ} \mathrm{C}$ until $100 \% \mathrm{CPE}$ was fully developed, and supernatants were then harvested and clarified by centrifugation $(425 \times g)$ for $10 \mathrm{~min}$ at $4^{\circ} \mathrm{C}$. The supernatants were decanted from the cell pellet and $0.45 \mu \mathrm{m}$-filtered followed by high-speed centrifugation $(103900 \times g)$ for $3 \mathrm{~h}$ at $4^{\circ} \mathrm{C}$. The resultant viral pellets were re-suspended in $300 \mu$ phosphatebuffered saline (10 mM; pH 7.4). RNase-treatment, viral RNA extraction, DNase treatment and generation of complementary DNA (cDNA) from viral RNA by sequence independent single primer amplification random PCR were performed, as described previously (Mohr et al. 2015). The cDNA was fragmented and tagged with sequencing adapters via the Nextera XT DNA sample preparation kit (Illumina). Indexed cDNA was sequenced in pools of up to 5 isolates in libraries with each of 4 MiSeq Reagent Kits v2 (300 cycle) on the MiSeq Desktop Sequencer (Illumina).

Bioinformatic analysis of trimmed sequences was conducted with a combination of Geneious v7 (Biomatters) and CLC Genomics Workbench v8 (CLC Bio) sequence analysis software platforms. De novo sequence assembly by CLC Genomics Workbench generated 6-12 contigs of $>500 \mathrm{bp}$ for each isolate. BLASTn searches of the National Center for Biotechnology Information (NCBI) GenBank database did not provide significant alignments for the majority of contigs. Contigs derived from the CHSE-214 host cells were readily distinguished by alignment with Oncorhynchus spp. sequences and removed. The nucleotide alignment of unknown de novo assembled contigs for the 11 isolates identified consensus sequences for 8 putative segments. The consensus sequence for each segment was translated in all possible frames to enable the identification of proteins putatively encoded by the RNA. The raw sequence data for each isolate were read-mapped back to the consensus sequence for each segment to ensure the complete assembly of open reading frames (ORFs) for each segment of each isolate. The ORF data for each isolate have been submitted to GenBank (Table S1 in the Supplement; www.int-res.com/ articles/suppl/d139p035_supp.pdf).

All ORFs were aligned and pairwise distance comparisons for the percent nucleotide and translated amino acid identity were undertaken with Geneious Alignments. In addition, the ORFs of 3 isolates (9801382, 06-04216 and 14-01514) were compared with 3 representative viruses from each genus within the family Orthomyxoviridae, including rainbow trout orthomyxovirus (RbtOV), steelhead trout orthomyxovirus (SttOV) and tilapia lake virus (TiLV) rep- 
resentatives. Phylogenetic analyses using the neighbor-joining method with a bootstrap consensus tree being inferred from 10000 replicates were conducted using MEGA5 (Tamura et al. 2011). Evolutionary distances were calculated using the Tamura-Nei model. Trees were also inferred using the maximum likelihood methods in randomized axelerated maximum likelihood (RAxML) (Stamatakis 2014) and IQ-Tree (Nguyen et al. 2015), which did not change any of the tree topologies (data not shown).

\subsection{RNA-sequencing (RNA-seq) next generation sequencing data}

The POMV genome segments were also assembled de novo using transcript sequences from Illumina RNA-seq data. Cultures of the Atlantic salmon kidney cell line ASK (ATCC CRL-2747_FL), known to be susceptible to POMV, were infected with POMV (isolate 14-01514) at a titre of $10^{6.17} \mathrm{TCID}_{50} \mathrm{ml}^{-1}$ for $24 \mathrm{~h}$. Total RNA was isolated from the TCSN with a RNeasy kit (Qiagen) and transcripts sequenced as $100 \mathrm{bp}$ paired-end reads on a HiSeq 2000 sequencer (Illumina) at Macrogen (Republic of Korea) using the TruSeq stranded mRNA protocol. Paired-end reads were then mapped to the most recent assembly of the Atlantic salmon genome (ICSASG_v2; GenBank Accession No. GCF_000233375.1; Lien et al. 2016) using STAR (version 2.5.3a; Dobin et al. 2013). The unmapped reads ( 22 million reads, representing $68 \%$ of total reads in the sample) were used to assemble the POMV genome.

De novo sequence assembly was conducted using Trinity (version 2.8.4) and SPAdes (version 3.12.0) with default parameters for both programs, setting the strand-specific flag in Trinity to RF. Contigs derived from Trinity and SPAdes were then mapped to the POMV transcriptome (ORFs) using GMAP (release November 15, 2017) to generate a sequence alignment map (SAM) file that reported the identifier of the de novo assembled transcript and the location of the sequence on the POMV transcriptome. The resulting SAM files were converted to binary alignment map (BAM) files, sorted and indexed using SAMtools (version 1.3.1). Sorted BAM files of de novo assembled transcripts were visualised against the viral transcriptome using IGV viewer (version 2.4.14) to select the longest contigs that mapped to each ORF. Selected contigs, which included the noncoding ends or untranslated regions (UTR), were manually aligned to the ORFs using MEGA (version 7.0.26) to reconstruct the viral genome.
RNA-seq data were then re-mapped against the newly assembled viral genome using Bowtie2 (version 2.2.9). SAM files from Bowtie alignment were converted to BAM files, sorted, and indexed using SAMtools (version 1.3.1). Finally, to find the sequences of the 5' and 3' ends or UTRs, IGV viewer opened the sorted BAM files and extracted the consensus sequences with a read depth of at least 50 . Consensus sequences were calculated using the criteria described in Cavener (1987), where, if the frequency of a single nucleotide at a specific position was greater than $50 \%$ and greater than twice the number of the second most frequent nucleotide, it was assigned as the consensus nucleotide.

\subsection{Virus purification and identification of POMV proteins}

POMV isolate 14-01514 (derived from diseased Atlantic salmon) was used for purification and characterisation of viral proteins. To generate sufficient virus, CHSE-214 cells were grown in CellSTACK Culture Chambers (5-STACK; Corning) until approximately $90 \%$ confluency was achieved; the culture medium was decanted and replaced with maintenance medium (MEM + 2\% (v/v) FBS) containing virus at a multiplicity of infection (MOI) of 0.1. Infected cells were incubated at $15^{\circ} \mathrm{C}$ until all cells demonstrated CPE. TCSN was harvested and clarified by centrifugation at $3800 \times g$ for $30 \mathrm{~min}$ at $6^{\circ} \mathrm{C}$. The supernatant was centrifuged at $100000 \times g$ for $16 \mathrm{~h}$ at $6^{\circ} \mathrm{C}$ in an Avanti J-30I high-speed centrifuge (Beckman) to pellet the virus. Pelleted virus was further purified by sucrose density gradient centrifugation using continuous 20-60\% sucrose gradients. Virus-containing bands were collected and pelleted by high-speed centrifugation at $100000 \times g$ for $2 \mathrm{~h}$ at $4{ }^{\circ} \mathrm{C}$ then resuspended in TNE buffer (Tris- $\mathrm{HCl}, \mathrm{NaCl}$, EDTA). The presence of purified virus was confirmed by electron microscopic examination.

Purified POMV isolate 14-01514 was subjected to polyacrylamide gel electrophoresis (SDS-PAGE) to denature the virus and fractionate viral (and residual cellular) proteins. Protein bands, visualised with Coomassie Brilliant Blue and the PlusOne ${ }^{\circledR}$ Silver Staining kit (GE Biosciences), were excised and subjected to in-gel digestion with trypsin, and the resulting tryptic peptides were extracted for mass spectrometric analysis as described by Shiell et al. (2002). Peptides were analysed at the Bio21 Institute (Melbourne University) on an LTQ Orbitrap Elite mass spectrometer (Thermo Scientific) coupled to an Ultimate 
3000 RSLC nanosystem HPLC (Dionex). The nanoLC system was equipped with an Acclaim pepmap nanotrap column (Dionex) and an Acclaim pepmap analytical column (Dionex) running on a $3-80 \% \mathrm{CH}_{3} \mathrm{CN}$ containing $0.1 \%$ formic acid gradient over $25 \mathrm{~min}$. The LTQ Orbitrap Elite mass spectrometer was operated in the data-dependant mode, whereby spectra were acquired first in positive ion mode followed by high-energy collisional dissociation. Ten of the most intense peptide ions with charge states $\geq 2$ were isolated and fragmented using normalised collision energy of 35 and activation time of $0.1 \mathrm{~ms}$.

The Orbitrap MS data were analysed using Proteome Discoverer (Thermo Scientific version 2.1) with the SequestHT algorithm to match tandem MS/MS spectra of HPLC-separated peptides from the in-gel tryptic digests with theoretical mass spectra produced by in silico tryptic digestion of the POMV protein sequences. Search results were filtered by a single threshold where matches to proteins were reported only if the cross-correlation factor (Xcorr) was $>1.5$ for a singly charged peptide ion, $>2.0$ for a doubly charged peptide ion or $>2.5$ for a triply or greater charged peptide ion.

\subsection{Production and evaluation of rabbit anti-POMV serum}

Purified POMV isolate 14-01514 was used to immunise a male New Zealand white rabbit. Seventy micrograms of purified virus in a water-in-oil emulsion was prepared using CSIRO triple adjuvant (Prowse 2000) and injected subcutaneously and again 4 and $11 \mathrm{wk}$ later. Blood was collected $3 \mathrm{wk}$ after the final boost and the serum prepared. Immunoreactivity of the serum was assessed by Western blot analysis and immunocytochemistry (ICC).

Western blot analysis was performed on uninfected and POMV-infected CHSE-214 cell lysates assessed by SDS-PAGE. Proteins for immunoblot analysis were transferred from the gel to a polyvinylidene difluoride (PVDF) membrane at $200 \mathrm{~mA}$ for $1 \mathrm{~h}$ in $10 \mathrm{mM}$ CAPS ( $\mathrm{pH}$ 11), $10 \%(\mathrm{v} / \mathrm{v})$ methanol buffer then blocked for $1 \mathrm{~h}$ in $2.5 \%(\mathrm{v} / \mathrm{v})$ bluefin tuna serum in $20 \mathrm{mM}$ Tris (pH 7.4), $150 \mathrm{mM} \mathrm{NaCl}, 0.05 \%$ (v/v) Tween 20 (TBST). Primary antisera and secondary horseradish peroxidase (HRP)-conjugated goat antirabbit antibody (Bio-Rad Laboratories) were diluted in TBST 1:10000 and 1:20 000, respectively. Transfer membranes were incubated with each antibody preparation for $1 \mathrm{~h}$ each at room temperature on a rocking platform. Membranes were washed with
TBST after incubation with primary and secondary antibodies. Enhanced chemiluminescence using ECL Plus substrate (Thermo Scientific Pierce) was used to detect immune-reactive bands with visualisation using a Typhoon FLA9000 fluorescence scanner (GE Biosciences).

Immunocytochemical reactivity of anti-POMV serum was assessed using POMV 14-01514, Tasmanian aquabirnavirus (isolate TABV 98-00047), Tasmanian Atlantic salmon aquareovirus (isolate TSRV 0000357) and a reference strain of ISAV (ISAV isolate Glesvaer 2/90) cultivated in CHSE-214, bluegill fry (BF-2; ATCC CCL 91), CHSE-214 and ASK cell cultures, respectively. Virus titration plates were prepared by inoculating 10 -fold dilutions of each virus onto $90 \%$ confluent cell monolayers grown in 96-well tissue culture plates (NUNC). At 3-10 d p.i., the virus-infected cell cultures were fixed in a cold acetone/methanol solution (1:1) for $30 \mathrm{~min}$. Fixed cells were rinsed 3 times with Dulbecco's phosphatebuffered saline A, pH 7.3 (PBSA) then twice with PBSA containing $0.05 \%$ (v/v) Tween 20 (PBST). Dilutions of primary sera were prepared in PBSA containing $1 \%$ skim milk powder. The diluted antibodies were overlaid onto the cells and incubated for $1 \mathrm{~h}$ at $37^{\circ} \mathrm{C}$ on a plate shaker with gentle agitation. Cells were rinsed 3 times with PBST then secondary HRPconjugated anti-rabbit IgG, diluted 1:1000 in PBSA containing $0.1 \%$ skim milk powder, was added to each well of the plate and incubated for $1 \mathrm{~h}$ with gentle shaking at $37^{\circ} \mathrm{C}$. Cells were rinsed 3 times with PBST. Substrate solution (20 mg 3-amino-9ethylcarbazole [Sigma Aldrich], $2.5 \mathrm{ml}$ dimethyl formamide, $0.05 \mathrm{M}$ acetate buffer [pH 5.0], $25 \mu \mathrm{l}$ hydrogen peroxide) was added to each well and incubated for $20 \mathrm{~min}$ in the dark at room temperature. Substrate solution was removed and cells were rinsed twice with deionised water to stop colour development. Cells were counterstained with Mayer's haematoxylin for $1 \mathrm{~min}$, rinsed twice with deionised water, and Scott's tap water (blueing solution) was added for $1 \mathrm{~min}$ before a final rinse. The cells were allowed to air-dry prior to examination by inverted light microscopy. Normal animal (e.g. rabbit or mouse) sera were used as negative controls.

\subsection{Development of diagnostic PCR tests}

To detect POMV, a reverse transcriptase real-time TaqMan polymerase chain reaction (RT-qPCR) and conventional reverse transcriptase nested PCR (RT$\mathrm{nPCR}$ ) were designed. The purpose of the POMV RT- 
qPCR was as a highly sensitive and highly specific screening assay. The POMV RT-nPCR was designed to be performed as a confirmatory assay in combination with amplicon sequencing, for use with samples testing positive with the POMV RT-qPCR. The POMV RT-qPCR targeted the putative polymerase acidic (PA) ORF, encoded by Segment 5. The POMV RT-nPCR was designed to target the polymerase subunit, PB1 ORF, encoded by Segment 2. The RT-qPCR and RT-nPCR assays targeted different segments of the POMV genome to increase confidence when a positive detection was obtained in both assays from the one test sample.

The approach to the design of primers and probe for RT-qPCR and primers for the RT-nPCR assays was similar. In each case, the entire ORF for each of the 11 POMV isolates was aligned in conjunction with representative ORF sequences from European and North American lineages of ISAV (McCauley et al. 2012) that encoded homologous proteins to those identified in POMV. Potential primer- and probebinding sites were identified that were identical among POMV isolates and contained at least 10 mismatches with aligned ISAV sequences.

Following clarification by centrifugation at $10000 \times g$ for $5 \mathrm{~min}$, total nucleic acid was extracted from $140 \mu \mathrm{l}$ aliquots of TCSNs or $50 \mu \mathrm{ll}$ aliquots of tissue homogenates, using the QIAamp viral RNA mini kit (Qiagen) or MagMAX-96 ${ }^{\mathrm{TM}}$ Viral RNA Isolation Kit on a MagMAX ${ }^{\mathrm{TM}}$ Express-96 Deep Well Magnetic Particle Processor (Life Technologies), respectively. Each POMV RT-qPCR assay was performed in a $25 \mu \mathrm{l}$ volume that contained $2 \mu \mathrm{l}$ extracted nucleic acid, $12.5 \mu \mathrm{l} 2 \times$ RT-PCR buffer, $1 \mu \mathrm{l}$ 25× RT-PCR enzyme mix (AgPath-ID ${ }^{\mathrm{TM}}$ One-Step RT-PCR, Life Technologies) and a final concentration of $900 \mathrm{nM}$ for forward primer 5'-ATC AGA AGG GAC GGT GGA AG-3' and reverse primer $5^{\prime}$-CGG TCT CGC AAC TCT TGA TTG-3' and $250 \mathrm{nM}$ for the probe $5^{\prime}-6$ FAMTCA AGC CCA AGG AAC CGC AAA AGCTAMRA-3' (amplifying 112 nucleotides). The quantitative PCR (qPCR) assays were performed in a 7500 Fast Real-Time PCR System (Life Technologies) with 30 min reverse transcription at $48^{\circ} \mathrm{C}$ followed by an initial 10 min denaturation at $95^{\circ} \mathrm{C}$, then 45 amplification cycles of $95^{\circ} \mathrm{C}$ for $15 \mathrm{~s}$ and $60^{\circ} \mathrm{C}$ for $60 \mathrm{~s}$.

For the POMV RT-nPCR, the primary RT-PCR assays were performed using a $25 \mu \mathrm{l}$ volume that contained $2 \mu \mathrm{l}$ extracted nucleic acid, $12.5 \mu \mathrm{l} 2 \times$ reaction mix and $1 \mu \mathrm{l}$ Superscript III/Platinum Taq mix (Invitrogen), $180 \mathrm{nM}$ forward primer POMVRTF (5'GAA GCA ATG GGA AGA GAG AC-3') and $180 \mathrm{nM}$ reverse primer POMVRTR (5'-GAC TCT GGA ACA
AGT CAT AGA TG-3'). The primary RT-PCR conditions involved an initial 30 min reverse transcription at $50^{\circ} \mathrm{C}$ followed by 2 min denaturation at $94^{\circ} \mathrm{C}$; then 35 amplification cycles of $94^{\circ} \mathrm{C}$ for $30 \mathrm{~s}, 55^{\circ} \mathrm{C}$ for $30 \mathrm{~s}$, $68^{\circ} \mathrm{C}$ for $60 \mathrm{~s}$; with a final extension at $68^{\circ} \mathrm{C}$ for $7 \mathrm{~min}$ to produce a $1281 \mathrm{bp}$ amplicon. The nested PCR had $2 \mu \mathrm{l}$ primary RT-PCR added to a $23 \mu \mathrm{l}$ reaction mix containing $12.5 \mu \mathrm{l}$ HotStarTaq Master Mix (Qiagen) and $360 \mathrm{nM}$ of forward primer POMVnF1 (5'-TCG AAT GGA GCG ACA AGC AC-3') and reverse primer POMVnR1 (5'-CTT GGT TGA CCA TCA CGC TTG-3'). The nPCR conditions involved an initial 15 min activation of the polymerase at $95^{\circ} \mathrm{C}_{i}$ followed by 35 amplification cycles of $94^{\circ} \mathrm{C}$ for $30 \mathrm{~s}$, $55^{\circ} \mathrm{C}$ for $30 \mathrm{~s}$ and $72^{\circ} \mathrm{C}$ for $30 \mathrm{~s}$; with a final extension at $72^{\circ} \mathrm{C}$ for $7 \mathrm{~min}$ to produce a $516 \mathrm{bp}$ amplicon. Selected amplicons were Sanger-sequenced using BigDye Terminator v 3.1 Cycle Sequencing chemistry and 3130xl Genetic Analyser (Applied Biosystems).

\subsection{Diagnostic PCR test validation}

\subsubsection{Analytical specificity (ASp)}

To determine inclusivity of both the POMV RTqPCR and RT-nPCR assays, nucleic acid extracted from 30 POMV isolates cultivated in piscine cell cultures were tested. To determine exclusivity, nucleic acid from Atlantic salmon gills, CHSE-214 cells, ASK cells and various finfish viruses were tested, including the following: ISAV (Glesvaer 2/90, Scotland 390/98 and Canada reference isolates), infectious haematopoietic necrosis virus (IHNV WRAC and 217/A isolates), viral haemorrhagic septicaemia virus (VHSV 23.75, DK-6137 and MI03GL isolates), salmonid alphavirus 1 (SAV-1), infectious pancreatic necrosis virus (IPNV Abild, Erwin and Sparjup isolates), Tasmanian Aquabirnavirus (TABV 10-01651 isolate), Tasmanian salmon Aquareovirus (TSRV 1202008 isolate), epizootic haematopoietic necrosis virus (EHNV) and nervous necrosis virus (NNV).

\subsubsection{Analytical sensitivity (ASe)}

Assessment of ASe was conducted by determining the limits of detection (LOD) for the POMV RT-qPCR using a DNA plasmid. An artificial construct was synthesised and cloned into pIDTBlue (Integrated DNA Technologies), as described by Snow et al. (2009). The construct contained a partial POMV 06-04216 
segment 5 sequence including target sequences for the POMV RT-qPCR primers and probe and artificial probe sequence (147 nucleotides in length). The concentration of the plasmid DNA was determined using a Qubit ${ }^{\mathrm{TM}}$ dsDNA HS Assay Kit for copy number calculations. The plasmid DNA was diluted 10-fold from $10^{7}$ to 1 copy per $\mu \mathrm{l}$ in water as well as a matrix of nucleic acid previously extracted from Atlantic salmon (kidney, liver and spleen) and the LOD determined from 5 wells tested per dilution.

\subsubsection{Diagnostic specificity (DSp)}

The 60 samples used for DSp were obtained from apparently healthy, adult (3 kg) Atlantic salmon, originating from Macquarie Harbour in Tasmania and sourced from the Centre for Aquatic Animal Health and Vaccines, Tasmanian Department of Primary Industries, Parks, Water and Environment (DPIPWE-CAAHV). The samples were comprised of pooled liver, kidney and spleen that were collected in 2015, prior to the first confirmed POMV detection in Macquarie Harbour that occurred in 2016.

\subsubsection{Diagnostic sensitivity (DSe) for detection in clinically affected fish}

To determine DSe for the POMV RT-qPCR from clinically infected Atlantic salmon, 81 samples were tested retrospectively. Forty-three samples consisted of pooled kidney, liver and spleen collected from individual Atlantic salmon between 2012 and 2013. The samples were originally submitted by the Animal Health Laboratory of DPIPWE for disease investigation, and POMV was isolated from each preparation of clarified $10 \%(\mathrm{w} / \mathrm{v})$ tissue homogenate. The homogenates and 28 POMV tissue culture-derived isolates had been stored (at CSIRO-AAHL) at $-80^{\circ} \mathrm{C}$. The 43 homogenates and 28 POMV isolates were thawed and retrospectively tested at the same time as 10 ethanol-fixed tissue samples of pooled gill, kidney and spleen that had been submitted as duplicate samples corresponding to the submitted fresh tissues.

\section{RESULTS}

\subsection{Virus isolation}

When inoculated onto a range of fish cell lines (including CHSE-214, RTG-2, EPC, FHM, BF-2, SHK-1,
ASK and PL), POMV readily infected CHSE-214, SHK-1 and PL cell cultures and demonstrated viral CPE as early as $4 \mathrm{~d}$ p.i. (Fig. 1), but this is temperature-dependent (Godwin et al. 2020). ASK cells are also susceptible to infection (Godwin et al. 2020). The cell lines RTG-2, EPC, FHM and BF-2 appeared to be refractory to infection.

\subsection{Electron microscopy}

Examination of ultrathin sections revealed the presence of circular to pleomorphic virus-like structures budding from the plasma membrane (Fig. 2A) and associated with intracellular vesicles (Fig. 2C). The particles ranged from 40 to $130 \mathrm{~nm}$ in diameter (measurements derived from examination of ultrathin sections) and possessed a limiting envelope and surface projections. An unusual structure identified within infected CHSE-214 cultures was the presence of tubular membrane projections. These structures appeared to lack surface projections, inner electrondense bands and granule-like internal structures. Individual surface projections were difficult to discern as were the presence of any associated distal structures/subunits, as observed with ISAV (Dannevig et al. 1995, Falk et al. 1997). However, detailed examination by NCEM revealed the presence of small white dots over the particle surface, most likely representing fine distal terminating structures (Fig. 2B). Intracytoplasmic viral particles were observed within membrane-bound cisternae (Fig. 2C). Also adsorbed to the grid substrate were free-lying ribonucleoproteins, which appeared as small super-coiled helices (Fig. 2D).

\subsection{POMV genome and protein characterisation}

The genomes of 3 orthomyxo-like viruses isolated from pilchards and 8 from Atlantic salmon (Table 1) were identified by a combination of de novo assembly and read mapping from NGS, MiSeq data. Each genome consisted of 8 segments regardless of the species of origin or year of isolation. The reads for segments 1 to 8 for each orthomyxo-like virus isolate accounted for $>80 \%$ of the total sequencing reads generated with an average nucleotide coverage of $>10000 \times$ for Segments 1, 2, 4, 5 and 6 while average coverage for Segments 3,7 and 8 was $>1000 \times$. The identity of Segments 1 to 6 was putatively assigned after NCBI BLASTp matches of translated proteins from each ORF that had low homology with ISAV 



Fig. 1. Photomicrographs of uninfected cell cultures of (A) PL, (D) CHSE-214 and (G) SHK-1 cell lines, at approximately $90 \%$ confluency showing normal cellular morphology. Cell cultures infected with an orthomyxo-like virus (98-01382) isolated from pilchards at $4 \mathrm{~d}$ post-infection (p.i.) and showing typical cytopathic effect (CPE) induced by viral infection in (B) PL, (E) CHSE214 and (H) SHK-1 cell lines. Cell cultures infected with orthomyxo-like virus (98-01382) at 5-6 d p.i. showing further development of the CPE (C) PL, (F) CHSE-214 and (I) SHK-1. Scale bar (applies to all panels) $=20 \mu \mathrm{m}$

proteins (Table 2). In contrast to ISAV, Segment 4 from each isolate encoded both a homologue to the fusion (F) protein from Segment 5 and a second ORF. The additional ORF had an overlap of 1 nucleotide in $\mathrm{a}+1$ coding frame that encoded protein $\mathrm{S} 4 \mathrm{~B}$, with 181 amino acids (aa) that had no significant NCBI BLASTp matches but shared conserved domains with DNA topoisomerases (Table S2). Segment 7 had 2 possible ORFs with an overlap of 269 nucleotides in $\mathrm{a}+1$ coding frame that encoded Proteins S7A and S7B. Segment 8 had a single ORF that encoded Protein S8A. The putative translated proteins (S7A, S7B and S8A) of Segments 7 and 8 also had no significant NCBI BLASTp matches. From the alignment of each ORF and protein from the 11 orthomyxo-like virus isolates sequenced, there was minimal diversity across $>95 \%$ nucleotide and $>98 \%$ aa identities
(Table S3). Therefore, the orthomyxo-like viruses isolated from pilchards and Atlantic salmon represented isolates of the same virus. The virus has hereafter been named pilchard orthomyxovirus (POMV) as the virus first isolated was from pilchards obtained from the Spencer Gulf, South Australia, in 1998.

Due to limitations of the methodology used to generate the NGS, MiSeq data, POMV segment ends could not be conclusively assembled. However, full-length POMV segments were assembled from RNA-seq generated NGS data obtained from ASK cells infected with POMV isolate 14-01514. The segments were identified from 4577 contigs assembled using SPAdes and 6794 contigs assembled with Trinity after the removal of Atlantic salmon reads. Comparison of the full-length POMV transcripts assembled confirmed the sequences of all the ORFs 



Fig. 2. Electron micrographs of orthomyxo-like virus (9801382) isolated from pilchards. (A) Ultrathin section revealing unusual tubular membrane projections in infected cells. (B) Negative contrast electron microscopy (NCEM) of roughly spherical viral particles. Arrowhead indicates the presence of surface projections. (C) An ultrathin section illustrating the presence of intracytoplasmic viral particles within membrane-bound cisternae and showing surface projections (thick arrow) and putative ribonucleoproteins (RNPs; thin arrows). (D) NCEM demonstrating free-lying RNPs (arrows). All scale bars $=100 \mathrm{~nm}$

obtained using the MiSeq approach for the same isolate (data not shown). Furthermore, analysis of the RNA-seq data had confirmed mRNA expression of all viral segments in ASK cells infected with POMV. In addition, the length of non-coding UTR consensus sequences at the $3^{\prime}$ end of POMV segments ranged between 7 and 85 nucleotides (Fig. 3A), and UTR sequences were highly conserved until Position 8. Only Segments 3 and 5 presented differences at Positions 5, 6 and 9. Segment 5 contained 1 additional nucleotide difference at Position 4 (Fig. 3B). Consensus UTR sequences at the 5 ' end of the viral mRNA ranged between 25 and 137 nucleotides, but conserved motifs were not identified (data not shown).

Purified POMV isolate 14-01514 proteins were denatured, separated and fractionated by protein gel electrophoresis (Fig. 4). Eleven discrete protein bands were identified, extracted and their tryptic peptides analysed by mass spectrometry. The translation and identity of 8 POMV proteins was confirmed with aa coverage ranging from 23 to $91 \%$ (Table 3). All proteins encoded by Segments 1 to 6 and Segment 8 that had been putatively identified based on NGS data assembly were confirmed,

Table 2. Comparison of pilchard orthomyxovirus (POMV), infectious salmon anaemia virus (ISAV) and rainbow trout orthomyxovirus (RbtOV) genome open reading frames (ORFs) and proteins. nt: nucleotides; aa: amino acids

\begin{tabular}{|c|c|c|c|c|c|c|c|c|c|}
\hline \multirow{2}{*}{ Segment } & \multicolumn{3}{|c|}{$\mathrm{POMV}_{-}$} & \multicolumn{3}{|c|}{ ISAV $^{\mathrm{a}}$} & \multicolumn{3}{|c|}{$\mathrm{RbtOV}^{\mathrm{b}}$} \\
\hline & Protein & ORF (nt) & Protein (aa) & Protein & ORF (nt) & Protein (aa) & Protein & ORF (nt) & Protein (aa) \\
\hline 1 & PB2 & 2199 & 732 & PB2 & 2166 & 722 & PB2 & 2184 & 727 \\
\hline 2 & PB1 & 2121 & 706 & PB1 & 2127 & 709 & PB1 & 2106 & 701 \\
\hline 3 & NP & 1971 & 656 & NP & 1851 & 616 & NP & 1917 & 638 \\
\hline \multirow[t]{2}{*}{4} & $\mathrm{~F}$ & 1350 & 449 & PA & 1737 & 579 & PA & 1767 & 588 \\
\hline & S4B & 546 & 181 & - & - & - & - & - & - \\
\hline 5 & PA & 1872 & 623 & $\mathrm{~F}$ & 1332 & 444 & $\mathrm{~F}$ & 1443 & 480 \\
\hline 6 & HE & 1398 & 465 & HE & 1167 & 389 & $\mathrm{HE}$ & 1395 & 464 \\
\hline \multirow[t]{2}{*}{7} & S7A & 885 & 294 & NS1 & 903 & 301 & NS1 & 921 & 306 \\
\hline & S7B & 339 & 112 & NEP & 477 & 159 & NEP & 432 & 143 \\
\hline \multirow[t]{2}{*}{8} & S8A & 621 & 206 & M1 & 591 & 197 & M1 & 624 & 207 \\
\hline & - & - & - & M2 & 726 & 242 & M2 & 708 & 235 \\
\hline
\end{tabular}




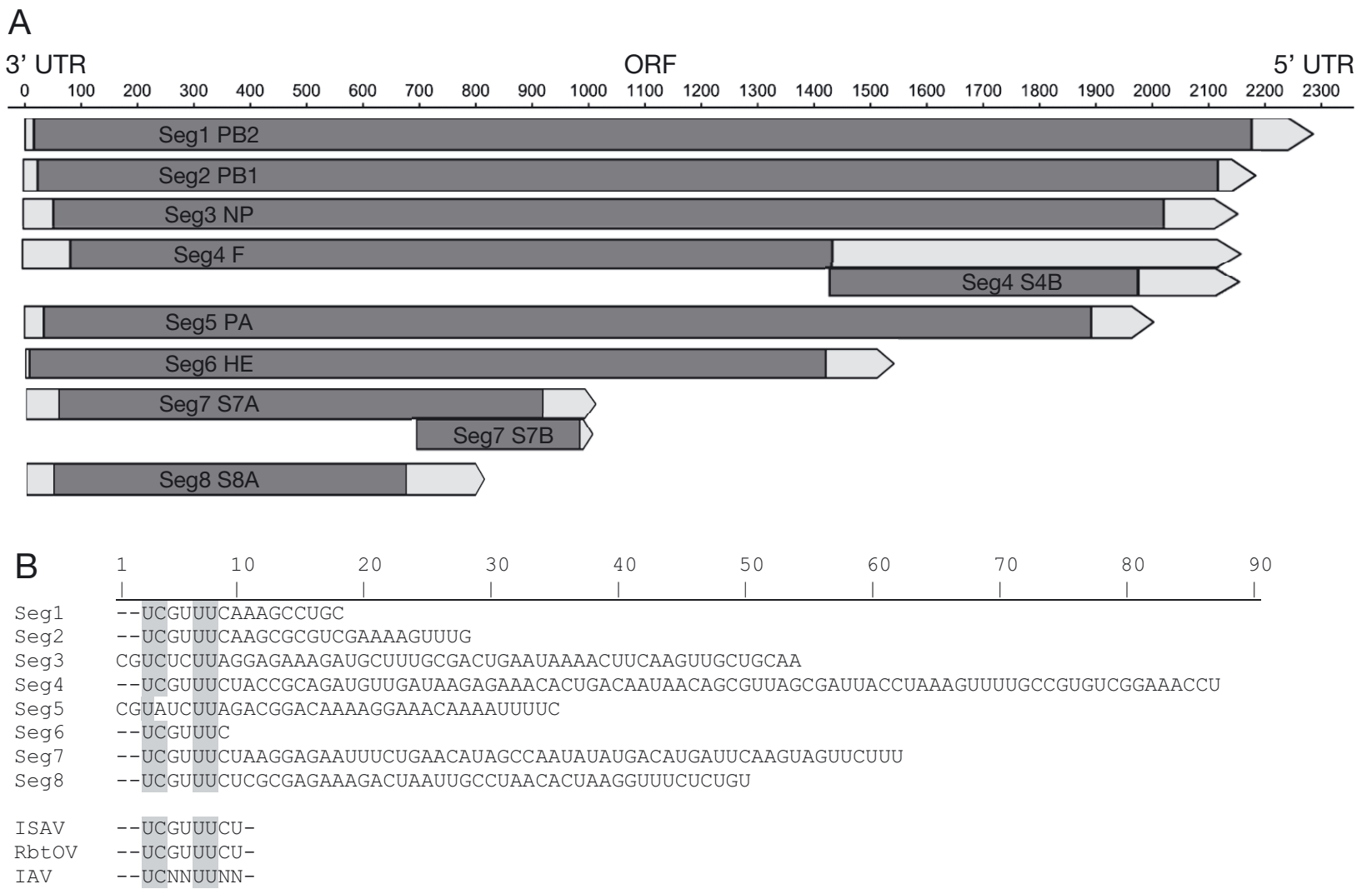

Fig. 3. De novo sequence assembly of pilchard orthomyxovirus (POMV) genomic segments (untranslated regions [UTR] and open reading frames [ORF]) from RNA-sequencing data. (A) Differences in length among the 8 genomic segments of POMV. (B) Consensus sequences at the 3' UTR for each segment. Nucleotides shaded in grey are conserved for all POMV segments and nucleotides conserved with segment consensus sequences for infectious salmon anaemia virus (ISAV) (Mérour et al. 2011), rainbow trout orthomyxovirus (RbtOV) (Batts et al. 2017) and Influenza A virus (IAV) (Díaz et al. 2014)

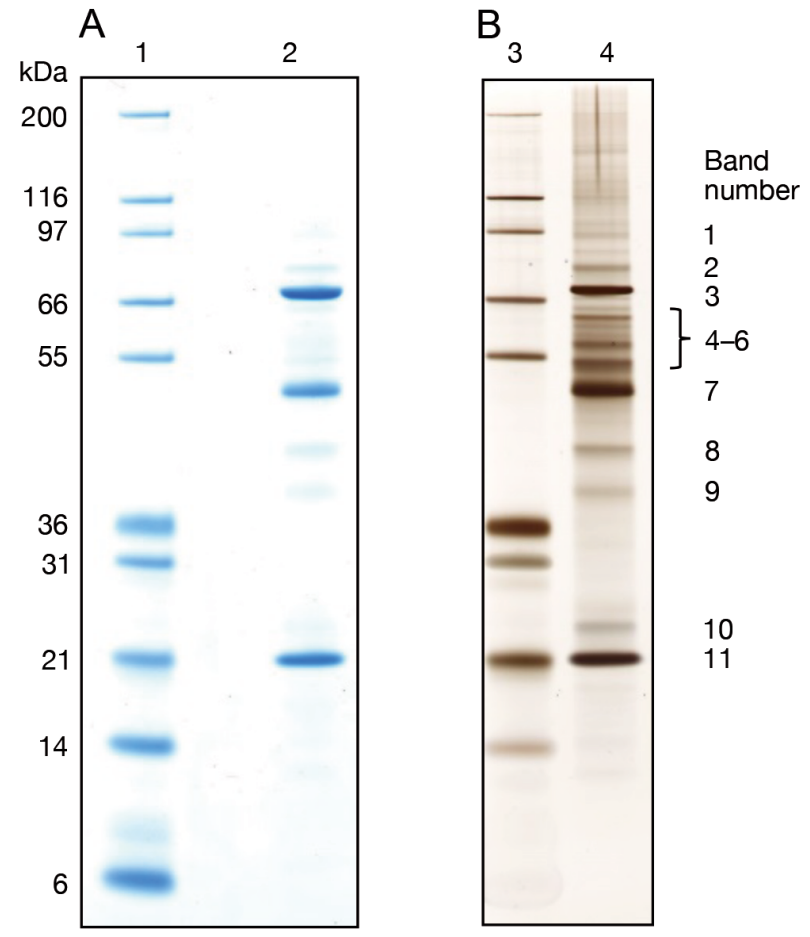

including proteins unique to POMV, S4B and S8A. Both putative proteins encoded by Segment 7 ORFs were not found in the peptide fragments analysed, possibly due to low abundance.

The PB1 gene is the most conserved within all viruses of the family Orthomyxoviridae; therefore a $P B 1$ phylogenetic tree was constructed to determine the relatedness of POMV to representatives of the 7 currently recognised genera (Fig. 5 \& Table S4). Other orthomyxoviruses isolated from fish included in the analysis were the rainbow trout orthomyxovirus and steelhead trout orthomyxovirus, both from the newly proposed genus Mykissvirus and the unique 10-segmented TiLV. A single clade assem-

Fig. 4. Identification of pilchard orthomyxovirus (POMV) proteins. Sodium dodecyl sulphate polyacrylamide gel electrophoresis (SDS-PAGE) separation of proteins derived from purified POMV visualized using (A) Coomassie Brilliant Blue stain and (B) silver stain. Eleven protein bands excised from gels for mass spectrometry analysis are indicated. Lanes 1 and 3: Mark12 marker (Invitrogen); Lanes 2 and 4: $5 \mu \mathrm{g}$ POMV 
Table 3. Pilchard orthomyxovirus (POMV) proteins from excised gel bands identified by mass spectrometry with corresponding amino acid coverage attained as a percentage of full-length protein

\begin{tabular}{|lrc|}
\hline $\begin{array}{l}\text { POMV } \\
\text { protein }\end{array}$ & Band no. & $\begin{array}{c}\text { Amino acid sequence } \\
\text { coverage (\%) }\end{array}$ \\
\hline PB1 & 1 & 43 \\
PB2 & 2 & 25 \\
& 1 & 44 \\
NP & 2 & 30 \\
& 3 & 78 \\
F & 4 & 51 \\
& 5 & 55 \\
S4B & 7 & 39 \\
PA & 8 & 38 \\
HE & 9 & 36 \\
& 10 & 23 \\
S8A & 3 & 49 \\
& 6 & 57 \\
& 7 & 79 \\
\end{tabular}

bled that included only the representative POMV isolates included in the analysis, isolated from pilchards in South Australia (98-01382) and Atlantic salmon in northern and southern Tasmania (0604216 and 14-01514, respectively). The POMV clade was most closely related to, but distinct from, Mykissvirus and Isavirus clades.

Phylogenetic analysis of POMV PB2, $P B 1, N P, F, P A$ and $H E$ ORFs identified 2 distinct clades for each ORF (Fig. 6 \& Table S5). The 2 clades that were detected for each ORF were predominantly due to unique single nucleotide polymorphism (SNP) patterns specific to each clade. The variation in isolates that clustered into the 2 clades for each ORF provided preliminary evidence of segment re-assortment between at least 2 populations of POMV segments within the isolates sequenced. As $S 4 B, S 7 A, S 7 B$ and $S 8 A$ ORFs are unique to POMV, and ISAV and RbtOV were used to root the phylogenetic trees, these ORFs could not be included in the phylogenetic analysis.

\subsection{Evaluation of anti-POMV serum}

Immunoblotting of a POMV-infected cell lysate and purified POMV with post-immunisation rabbit antisera demonstrated specific immunoreactivity with 3 viral proteins that had previously been identified by mass spectrometry: 65 kDa nucleoprotein (NP), $\sim 52 \mathrm{kDa}$ hemagglutinin-esterase (HE) and $\sim 25 \mathrm{kDa}$
S8A (Fig. 7A). The anti-POMV antiserum did not bind any proteins from an uninfected CHSE-214 cell lysate. Pre-bleed serum from the rabbit that was later immunised also showed no specific reactivity with POMVinfected cell lysate, purified POMV or an uninfected CHSE-214 cell lysate. Immunocytochemistry with anti-POMV antiserum using uninfected CHSE-214 cell cultures resulted in no observable staining (Fig. 7B). In contrast, POMV-infected CHSE-214 cell cultures, displaying typical $\mathrm{CPE}$, demonstrated extensive staining (Fig. 7C). No non-specific staining was observed when cell cultures infected with TABV, TSRV or ISAV and displaying CPE were incubated with the anti-POMV antiserum (data not shown).

\subsection{Preliminary diagnostic PCR test validation}

To assess the ASp, inclusivity, of the POMV RTqPCR and RT-nPCR assays, more than 30 POMV isolates were tested. All POMV isolates were detected by both assays and represented archived isolates from pilchards and Atlantic salmon collected in South Australian and Tasmanian waters from 1998 to 2014. Of the isolates amplified by the POMV RTnPCR, 16 nested amplicons were selected and Sanger-sequenced to represent isolates with different temporal, geographic and host species properties (Table S6). All amplicons sequenced were consistent with POMV Segment 2. Further analysis demonstrated complete nucleotide agreement between the Sanger sequences of the 7 POMV isolates with that generated by NGS for each isolate (data not shown). The ASp, exclusivity, of both the POMV RT-qPCR and RT-nPCR assays was demonstrated when nucleic acid extracted from a host species (Atlantic salmon tissue), or 2 cell lines routinely used for POMV isolation (CHSE-214 and ASK) were tested and amplification was not detected. Both assays also did not amplify nucleic acids purified from isolates representing European and North American lineages of ISAV or other viral pathogens of Atlantic salmon (IHNV, VHSV, IPNV, SAV-1, TABV and TSRV) or other finfish (EHNV and NNV).

The POMV RT-qPCR was designed as a highly specific and sensitive assay to screen samples, with the RT-nPCR designed as a confirmatory assay, in combination with amplicon sequencing, for positive detections obtained with the POMV RT-qPCR. Therefore, validation of ASe, DSe and DSp was undertaken with only the POMV RT-qPCR. When plasmid DNA was diluted in water the POMV RTqPCR LOD was at least 10 copies with all 5 wells at 


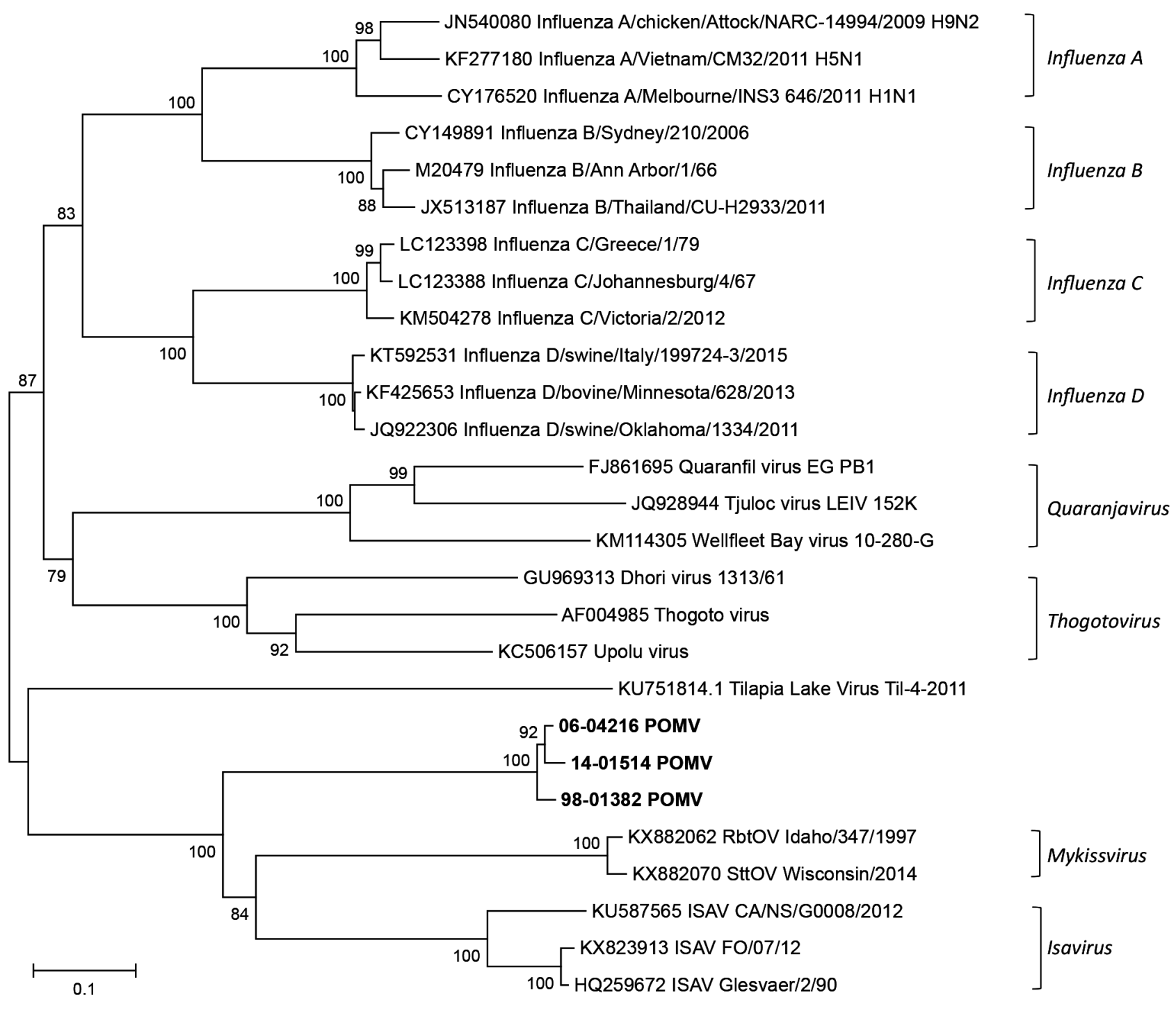

Fig. 5. Phylogenetic relationships of pilchard orthomyxovirus (POMV) $P B 1$ and other orthomyxoviruses inferred using the neighbor-joining method with 1125 nucleotides. Three representative members of Orthomyxoviridae genera Influenza $A$, Influenza $B$, Influenza $C$, Influenza D, Quaranjavirus, Thoratovirus and Isavirus as well as recently characterized orthomyxoviruses of fish; rainbow trout orthomyxovirus (RbtOV), steelhead trout orthomyxovirus (SttOV) (proposed genus Mykissvirus) and tilapia lake virus (TiLV). Three POMV sequences were included in the analysis, 98-01382 isolated from South Australian pilchards, and 06-04216 and 14-01514 isolated from Atlantic salmon from northern and southern Tasmania, respectively. The percentage of replicate trees in which the associated taxa clustered together $>70 \%$ in the bootstrap test (10 000 replicates) are shown next to the branches. The tree is drawn to scale, with branch lengths in the same units as those of the evolutionary distances used to infer the phylogenetic tree. All positions containing gaps and missing data were eliminated

that dilution testing positive. In contrast, when plasmid DNA was diluted in a matrix of Atlantic salmon nucleic acid the LOD was at least 100 copies with all 5 wells at that dilution testing positive.

A preliminary estimate of DSp for the POMV RTqPCR was performed with 60 known negative Atlantic salmon samples. All 60 samples tested negative for POMV, and therefore the estimate of DSp was $100 \%$. To estimate DSe a total of 81 known POMV positive samples that consisted of 43 tissue homogenates, 10 ethanol-fixed tissues and 28 tissue culture derived POMV isolates were tested by the POMV RT-qPCR assay. All 81 samples were positive with cycle threshold $\left(\mathrm{C}_{\mathrm{T}}\right)$ values that ranged from 13.8 to 32.7 for tissue homogenates, 18.7 to 30.3 for ethanol-fixed tissues and 11.3 to 22.2 for tissue culture-derived POMV isolates. Based on the testing of these samples, the DSe of 

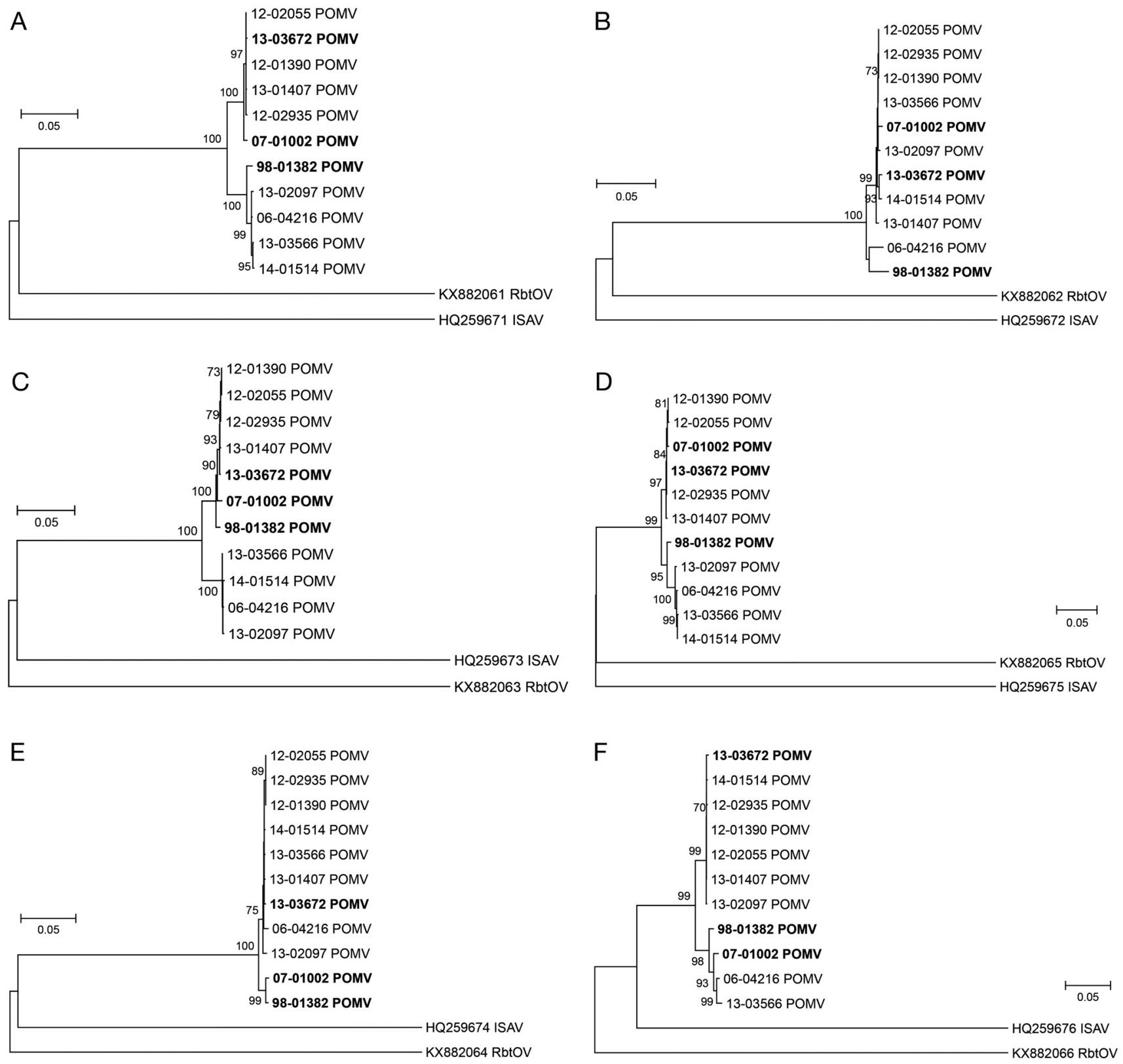

Fig. 6. Phylogenetic relationships of pilchard orthomyxovirus (POMV) (A) $P B 2$, (B) $P B 1$, (C) $N P$, (D) $F$, (E) $P A$, (F) $H E$ inferred using the neighbor-joining method. POMV isolated from pilchards are highlighted in bold. A representative infectious salmon anaemia virus (ISAV) (Glesvaer/2/90) and rainbow trout orthomyxovirus (RbtOV) (Rainbow/Idaho/347/1997) were included as the nearest related orthomyxoviruses to root the tree. The percentage of replicate trees in which the associated taxa clustered together $>70 \%$ in the bootstrap test (10 000 replicates) are shown next to the branches. The tree is drawn to scale, with branch lengths in the same units as those of the evolutionary distances used to infer the phylogenetic tree. All positions containing gaps and missing data were eliminated

the POMV RT-qPCR for testing tissues for clinically affected animals was $100 \%$. It is important to note that a determination of DSe and DSp for surveillance testing can only be achieved through testing of sub-clinically infected, apparently healthy animals, and this is yet to occur.

\section{DISCUSSION}

This report describes the initial isolation and preliminary characterisation of an orthomyxo-like virus isolated, in the first instance, from apparently healthy pilchards and, subsequently, from diseased 

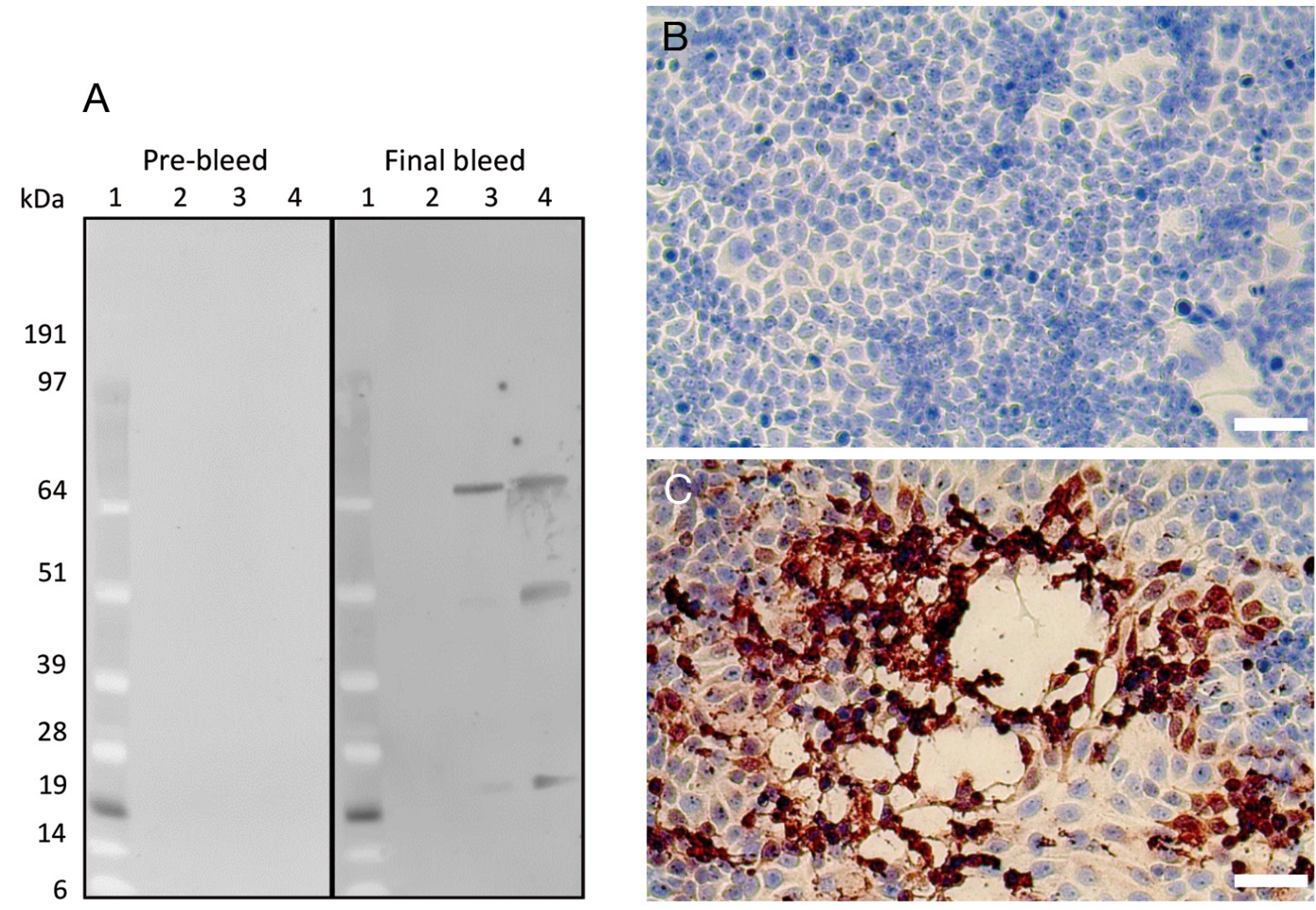

Fig. 7. Rabbit anti-pilchard orthomyxovirus (POMV) serum reactions with POMV protein. (A) Western blot using rabbit preimmune and anti-POMV sera diluted 1:10 000. Lane 1: Blue Plus 2 molecular weight (MW) markers; Lane 2: uninfected CHSE214 cell lysate; Lane 3: POMV 14-01514-infected cell lysate; Lane 4: purified POMV 14-01514. Immunocytochemistry of fixed (B) uninfected and (C) POMV-infected CHSE-214 cell cultures using rabbit anti-POMV serum diluted 1/200000. Scale bars $=50 \mu \mathrm{m}$

Atlantic salmon, in Australia. Studies demonstrating the role of POMV in the disease of Atlantic salmon, salmon orthomyxoviral necrosis, have been reported by Godwin et al. (2020). The results presented here demonstrate that the virus isolated from healthy pilchards was the same as that isolated from diseased Atlantic salmon and only distantly related to other piscine orthomyxoviruses. Since the virus was first isolated from pilchards it is proposed that the species be named Pilchard orthomyxovirus (POMV). It is interesting to note that the virus was first discovered in apparently healthy pilchards and then, only some years later, in diseased farmed Atlantic salmon, demonstrating interspecies transmission, which is well-documented in other orthomyxoviruses (McCauley et al. 2012). Moreover, POMV replicates in cell lines of both pilchard and salmon origin. Other evidence supporting classification of POMV as an orthomyxovirus includes the ability to agglutinate host erythrocytes (Godwin et al. 2020).
The International Committee on Taxonomy of Viruses (ICTV), in the 2017 virus taxonomy release, recognised 7 genera within the family Orthomyxoviridae. The only recognised genus with viruses that infect fish is Isavirus with a single species, ISAV, that has been reported to cause infectious salmon anaemia in Atlantic salmon (Falk et al. 1995). Recently characterised RbtOV and SttOV, isolated from Oncorhynchus mykiss in the USA, have diverged sufficiently from ISAV to be proposed as representing a new genus Mykissvirus (Batts et al. 2017). The TiLV isolated in Israel from tilapia species and identified as a unique orthomyxo-like virus with 10 linear genome segments also represents potentially another new genus (Eyngor et al. 2014, Bacharach et al. 2016). Phylogenetic analysis of POMV PB1 sequences, in comparison to representative viruses of the 7 recognised Orthomyxoviridae genera, as well as proposed Mykissvirus genus and TiLV, indicate that POMV is the type species of a new genus within the family Orthomyxoviridae tentatively named Sardino- 
virus. Further supporting this proposal is the identification of 4 novel ORFs that are putatively assigned to encode proteins with no known orthologs, as well as evidence of a high divergence in non-coding sequence regions of POMV segments.

A combination of complementary NGS approaches (MiSeq and RNA-seq) enabled the assembly and confirmation of the complete POMV genome for the first time. Moreover, subsequent protein mass spectrometric analysis was able to confirm that 8 of the 10 putative proteins encoded by the assembled segments were present in purified virions. However, proteins encoded by Segment 7 were unable to be identified by this technique, and confirmation requires further analysis. Comparison of the various genome segments between isolates also identified that segment reassortment had occurred between 2 populations for each segment that was not attributable to the date of POMV isolation, geographical location, health status of the host or host species. Segment reassortment is common among other orthomyxoviruses, including ISAV (Plarre et al. 2012); however, its relevance for POMV to cause disease or species specificity in Atlantic salmon or pilchards requires further investigation.

Originally, confirmation of POMV in diseased Atlantic salmon was only possible with a combination of virus isolation and electron microscopy, a process that required several weeks to complete. The development of the anti-POMV rabbit antiserum, that was demonstrated to be specific for POMV, potentially shortens the process of confirming POMV, following CPE development and detection in cell culture. Subsequently, a real-time TaqMan PCR and a conventional nested PCR were designed to enable even more rapid detection and confirmation of POMV from cell cultures or fish tissues, thereby significantly reducing the process time (from sample submission to confirmatory diagnosis) to a matter of days. Preliminary validation of the new PCR methods indicates that the assays are highly sensitive and highly specific. However, the ability of the real-time TaqMan PCR to detect POMV in apparently healthy animals was not assessed and should be demonstrated before its use in surveillance activities.

Acknowledgements. This research was supported by funding from the Fisheries Research and Development Corporation on behalf of the Australian Government (FRDC Project No 2013-033) and the Tasmanian Salmonid Growers' Association. We thank Drs. Jeremy Carson, Richard Morrison and Scott Godwin (Department Primary Industries Parks
Water and Environment, Tasmania, Australia) for their collaboration during the project and their review and editing of the manuscript. We thank the following sources of finfish viruses used for analytical sensitivity testing of POMV PCR assays: Dr. Birgit Dannevig, National Veterinary Institute, Norway (ISAV), Dr. Jim Winton, Western Fisheries Research Center, USA (IHNV), Dr. Niels Olesen, Danish Technical University of Denmark, Denmark (VHSV), Dr. David Graham, Agrifood and Biosciences Institute, UK (SAV1) and Drs. Barry Hill and Keith Way, CEFAS Weymouth, UK (IPNV). We also thank the CSIRO AAHL Sequencing, Histology and Small Animal Facility groups for their contributions to this research.

\section{LITERATURE CITED}

Bacharach E, Mishra N, Briese T, Zody MC and others (2016) Characterization of a novel orthomyxo-like virus causing mass die-offs of tilapia. MBio 7:e00431-e16

Batts WN, LaPatra SE, Katona R, Leis E and others (2017) Molecular characterization of a novel orthomyxovirus from rainbow and steelhead trout (Oncorhynchus mykiss). Virus Res 230:38-49

Cavener DR (1987) Comparison of the consensus sequence flanking translational start sites in Drosophila and vertebrates. Nucleic Acids Res 15:1353-1361

Cottet L, Rivas-Aravena A, Cortez-San Martin M, Sandinoa AM, Spencer E (2011) Infectious salmon anemia virus genetics and pathogenesis. Virus Res 155:10-19

Dannevig BH, Falk K, Namork E (1995) Isolation of the causal virus of infectious salmon anaemia (ISA) in a longterm cell line from Atlantic salmon head kidney. J Gen Virol 76:1353-1359

Díaz Á, García K, Navarrete A, Higuera G, Romero J (2014) Virtual screening of gene expression regulatory sites in non-coding regions of the infectious salmon anaemia virus. BMC Res Notes 7:477

Dobin A, Davis CA, Zaleski C, Schlesinger F and others (2013) STAR: ultrafast universal RNA-seq aligner. Bioinformatics 29:15-21

Eyngor M, Zamostiano R, Kembou Tsofack JE, Berkowitz A and others (2014) Identification of a novel RNA virus lethal to tilapia. J Clin Microbiol 52:4137-4146

Falk K, Press CMcL, Landsverk T, Dannevig BH (1995) Spleen and kidney of Atlantic salmon (Salmo salar L.) show histochemical changes early in the course of experimentally induced infectious salmon anaemia (ISA). Vet Immunol Immunopathol 49:115-126

Falk K, Namork E, Rimstad E, Mjaaland S, Dannevig BH (1997) Characterisation of infectious salmon anaemia virus, an orthomyxo-like virus isolated from Atlantic salmon (Salmo salar L.). J Virol 71:9016-9023

Fijan N, Sulimanovic D, Bearzotti M, Muzinic D and others (1983) Some properties of the epithelioma papulosum cyprini (EPC) cell line from carp Cyprinus carpio. Ann Virol (Inst Pasteur) 134E:207-220

Godwin SE, Morrison RN, Knowles G, Cornish MC, Hayes D, Carson J (2020) Pilchard orthomyxovirus (POMV). II. Causative agent of salmon orthomyxoviral necrosis, a new disease of farmed Atlantic salmon Salmo salar. Dis Aquat Org 139:51-68

Hyatt $\mathrm{AD}$, Hine PM, Jones $\mathrm{B}$, Whittington $\mathrm{R}$ and others (1997) Epizootic mortality in the pilchard Sardinops sagax neopilchardus in Australia and New Zealand in 
1995. II. Identification of a herpesvirus within the gill epithelium. Dis Aquat Org 28:17-29

Lien S, Koop BF, Sandve SR, Miller JR and others (2016) The Atlantic salmon genome provides insights into rediploidization. Nature 533:200-205

McCauley JW, Hongo S, Kaverin NV, Kochs G and others (2012) Orthomyxoviridae. In: King AMQ, Lefkowitz E, Adams MJ, Carstens EB (eds) Virus taxonomy: Ninth Report of the International Committee on Taxonomy of Viruses. Academic Press, San Diego, CA, p 749-761

Mérour E, LeBerre M, Lamoureux A, Bernard J, Brémont M, Biacchesi S (2011) Completion of the full-length genome sequence of the infectious salmon anemia virus, an aquatic orthomyxovirus-like, and characterization of mAbs. J Gen Virol 92:528-533

Mohr PG, Moody NJG, Williams LM, Hoad J, Crane MStJ (2015) Molecular characterization of Tasmanian aquabirnaviruses from 1998 to 2013. Dis Aquat Org 116:1-9

Nguyen LT, Schmidt HA, Von Haeseler A, Minh BQ (2015) IQ-TREE: a fast and effective stochastic algorithm for estimating maximum-likelihood phylogenies. Mol Biol Evol 32:268-274

OIE (2019a) Infection with HPR-deleted or HPR0 infectious salmon anaemia virus. Chapter 2.3.5. In: Manual of diagnostic tests for aquatic animals. OIE, Paris. www.oie. int/index.php?id=2439\&L=0\&htmfile=chapitre_isav.htm

OIE (2019b) General information. Chapter 2.3.0. In: Manual of diagnostic tests for aquatic animals. OIE, Paris. www.oie.int/index.php?id=2439\&L=0\&htmfile=chapitre general_information_2_3.htm

Plarre H, Nylund A, Karlsen M, Brevik Ø, Sæther PA, Vike S

Editorial responsibility: James Jancovich, San Marcos, California, USA
(2012) Evolution of infectious salmon anaemia virus (ISA virus). Arch Virol 157:2309-2326

Prowse S (2000) A new adjuvant. ANZCCART News 13:7

Shiell BJ, Beddome G, Michalski WP (2002) Mass spectrometric identification and characterisation of the nucleocapsid protein of Menangle virus. J Virol Methods 102: 27-35

Snow M, McKay P, Matejusova I (2009) Development of a widely applicable positive control strategy detection of infectious salmon anaemia virus (ISAV) using TaqMan real-time PCR. J Fish Dis 32:151-156

Stamatakis A (2014) RAxML version 8: a tool for phylogenetic analysis and post-analysis of large phylogenies. Bioinformatics 30:1312-1313

Tamura K, Peterson D, Peterson N, Stecher G, Nei M, Kumar S (2011) MEGA5: molecular evolutionary genetics analysis using maximum likelihood, evolutionary, distance, and maximum parsimony methods. Mol Biol Evol 28: 2731-2739

Whittington RJ, Jones JB, Hine PM, Hyatt AD (1997) Epizootic mortality in the pilchard Sardinops sagax neopilchardus in Australia and New Zealand in 1995. I. Pathology and epizootiology. Dis Aquat Org 28:1-16

Williams LM, Crane MStJ, Gudkovs N (2003) Development and characterisation of pilchard (Sardinops sagax neopilchardus) cell lines derived from liver and heart tissues. Methods Cell Sci 25:105-113

Winton J, Batts W, de Kinkelin P, LeBerre M, Brémont $M$, Fijan N (2010) Current lineages of the epithelioma papulosum cyprini (EPC) cell line are contaminated with fathead minnow, Pimephales promelas, cells. J Fish Dis 33: 701-704

Submitted: December 3, 2019; Accepted: March 4, 2020 Proofs received from author(s): April 27, 2020 